of about 10,000 air photographs. Those who know Cyprus will be aware of the meaning to be attached to such mixed categories as "tree and other perennial crops with unimproved grazing land"; but those who do not are liable to draw incorrect conclusions unless they have been forewarned. The Island's land is about equally divided between crop land and unimproved grazing land and forest together, which says much for the persistence and patience of the Cypriots who cultivate the land, often with simple implements, and also for the work of the Forestry Department which has been enabled, by legislation and other methods, to do so much for the re-establishment of the forests. Changing age-old methods of cultivation and overcoming fragmentation of holdings makes the Agricultural Department's task more difficult. The map is well produced, and clearly printed so that detail can be seen without difficulty.

\section{Distribution of Mistletoe}

A SHORT account of the way mistletoe is distributed is given by D. J. Cove in The Starfish, the journal of the Association of School Natural History Societies (No. 9 ; July 1956). The inquiries started in the Bishop's Stortford district and have now developed into a national survey. Tentative conclusions show that mistletoe is mainly found in old trees and indicate that man, rather than birds, is the chief agent in distribution. On the larger trees, mistletoe tends to grow near the apex of the crown, or towards the sides, where it is beyond the easy reach of man. One possible explanation for this, which does not involve man, is that the light is too weak in the centre of the tree for photosynthesis in mistletoe to take place. Another explanation is that the birds distributing the seeds tend to frequent the outer parts of the tree's canopy. It is evident from the records submitted that, although Viscum grows on a wide range of hosts, distribution through this range is very uneven. Of the thirteen families involved, the Rosaceae alone account for nearly 70 per cent of the infested plants ; and apple trees are the commonest hosts by far (42 per cent). Records of host-plants which are particularly worth noting include Parrotia, silver fir and, in view of its association with mistletoe at the festive season, holly. In spite of all that one reads about the attention paid by Druids to mistletoe growing on oak, only a single case of an infested oak has been reported. The present survey has produced some circumstantial evidence in support of the existence of 'strains' differing in the range of hosts they infest. More records will be needed before firm conclusions can be made about the validity or otherwise of these 'strains'.

New Zealand Forest Service : Report for 1954-55

THE annual report of the Forest Department of New Zealand, covering the period April 1954-March 1955 (pp. 103. Wellington: N.Z. Forest Service, 1955 ), commences by commenting on the remaining indigenous forests of the country which, after being completely ignored during the great exotic coniferous campaign of the earlier years of this century, have been receiving attention for some years. They are sylviculturally necessary as an insurance against widespread devastation of the exotic forests by disease or fire, in addition to being a source of invaluable specialist timber. A long-term objective for this indigenous forest is to bring as much as possible as soon as possible into a state of greatest productivity. Until recently, it was considered that conservation was best served by complete control of the indigenous cut. This has proved impracticable. The approach is now to be sylvicultural, and this is of considerable interest. 'The area is to be regenerated, artificially or naturally, with the main native forest timber species-the kauri, the podocarps and the beeches. Practice in Queensland, Australia, and research in New Zealand offer evidence that kauri can be artificially established as a productive crop. The good conifers have been subject to intensive study, and new management methods begun. The beech forest, so long neglected, shows great promise under management, and beech timbers are now widely used and respected. An interesting introduction is a Forest Biology Survey for the purpose of detecting population build-ups of any forest organism; thus outbreaks of insects or disease may be dealt with in their early stages.

\section{Zoological Nomenclature}

THe International Commission on Zoological Nomenclature will start to vote, as from February 24, 1957 , on the following cases involving the possible use of its plenary powers, full details of which have already been published (Bull. Zool. Nom., 12, Pts. 68; August 24, 1956): (1) alligator Blumenbach, 1779 (Lacerta), suppression, to protect mississipiensis Daudin [1801-1802], (Crocodilus) (c1. Reptilia); (2) Campsicnemus Haliday, 1851, validation (cl. Insecta, order Diptera); (3) Elaphella Bezzi, 1913, and Lophiotherium Gervais, 1850, validation (cl. Mammalia) ; (4) verrucosa Sars, 1901 (Alona), validation (cl. Crustacea, order Cladocera); (5) Candona Baird, [1846], designation of type species for and Herpetocypris (emend. of Erpetocypris) Brady and Norman, 1899, validation (cl. Crustacea, order Ostracoda); (6) Conchoecia (emend. of Conchaecia) Dana, 1849, validation of and designation of type species for (cl. Crustacea, order Ostracoda) ; (7) Anchisauripus Lull, 1904, and Otouphepus and magnificus (Otouphepus), both of Cushman, 1904, suppression (cl. Reptilia Theropoda [Ichnites]). Comments should be sent as soon as possible to the secretary to the Commission, Francis Hemming, 28 Park Village East, Regent's Park, London, N.W.1.

\section{Folk-Lore}

THE note in Nature of September 8, p. 522, on Gwerin, the new journal of folk-lore, ends with the sentence: "There is, indeed, room for a journal devoted to folk-lore, and all will wish the new venture every success". It has been pointed out to the Editors that this might give the impression that Gwerin is the only periodical devoted to folk-lore. This, of course, is not the case, for the periodical Folk-Lore, the quarterly journal of the Folk-Lore Society (c/o University College, Gower Street, London, W.C.1), has been in existence since 1878 and is still an excellent publication (often referred to in Nature) which deals with every aspect of folkbelief, tradition, custom and folk-lore research both in Great Britain and elsewhere.

\section{Oversea Service Division, Colonial Office}

THE following appointments have recently been made in the Oversea Service Division, Colonial Office : H. Bailey (agricultural officer, Gambia), agricultural officer, Northern Region, Nigeria; J. D. A. Harris (agricultural officer, Sierra Leone), senior agricultural officer, Western Region, Nigeria; H. P. Burgess (conservator of forests, Western Region, Nigeria), 